$\xi=-1$

\title{
Temporal Variation of Coastal Groundwater Quality in East Coast of Terengganu, Malaysia
}

\author{
Norsyuhada Hairoma ${ }^{1}$, Muhammad Barzani Gasim ${ }^{1,2^{*}}$, Mohd Ekhwan Toriman ${ }^{3}$, Hafizan Juahir ${ }^{1}$, Azman Azid ${ }^{4}$, \\ Mohammed Hatta Abd Karim ${ }^{1}$, Mohd Khairul Amri Kamarudin ${ }^{1}$, Mazlin Mokhtar ${ }^{5}$, Rahmah Elfitri ${ }^{5}$ \\ ${ }^{\text {I}}$ East Coast Environmental Research Institute (ESERI), Universiti Sultan Zainal Abidin, Gong Badak Campus, 21300 Kuala Nerus, Ter- \\ engganu, Malaysia \\ ${ }^{2}$ Faculty of Bio Resources and Food Industries Universiti Sultan Zainal Abidin, Tembila Campus, 22200 Besut, Terengganu, Malaysia \\ ${ }^{3}$ Faculty of Social Sciences and Huminities, Universiti Kebangsaan Malaysia, 43600 Bangi, Selangor, Malaysia \\ ${ }^{4}$ UniSZA Science and Medicine Foundation Centre, Universiti Sultan Zainal Abidin, Gong Badak Campus, 21300 Kuala Nerus, Tereng- \\ ganu, Malaysia \\ ${ }^{5}$ Institute for Environment and Development, Universiti Kebangsaan Malaysia, 43600 Bangi, Selangor, Malaysia \\ *Corresponding Author: drbarzani@gmail.com
}

\begin{abstract}
Coastal groundwater is extremely vulnerable to saltwater contamination. This study was conducted to investigate the potential contamination of saltwater into coastal groundwater temporally. Data was obtained from PT000017 monitoring well from 2006 to 2012 . Nine parameters of water quality were involved for data analyses. Two main diagrams used for data analyses are piper diagram and hydrochemical facies evolution diagram (HFE-D). All parameters were plotted to produce a piper diagram that determine the water type between different seasons. During wet season, groundwater samples are located in domain III that represent mixed Ca-Na-HCO3 water type; 2007 groundwater sample was located in domain I, represent Ca-HCO3 water type and during 2008 groundwater sample was located in domain II, represent $\mathrm{Na}-\mathrm{Cl}$ water type. During dry season, groundwater samples are located in domain II that represent mixed $\mathrm{Ca}$ Na-HCO3 water type meanwhile, 2009 and 2011 groundwater samples are located in domain I, represent Ca-HCO3 water type. Subsequently, HFE-D diagram was produced to determine the evolution process of salinization or freshening of coastal groundwater. In this study, all of groundwater samples were in freshening stage except during dry season 2007 groundwater sample was in the phase of saltwater intrusion.
\end{abstract}

Keywords: Coastal groundwater; Terengganu; saltwater; HFE-D; piper diagram.

\section{Introduction}

The total of earth populations increases progressively year by year. As the population increases, the necessities to sustain life are also increases. People need water for domestic activities, recreational activities, agriculture, fisheries, livestock, irrigation, water transportation and sustainability of water related industry [1]. Food production is also highly dependent on adequate water supply for cultivation and processing activities. For that reason, people exploit the available freshwater on the earth to the maximum uses. Groundwater and surface water are the main clean water supply to humankind for drinking purpose. However, both groundwater and surface water must be treated before use. Seawater is not included in freshwater category and it is not drinkable because of its high salinity. At coastal area, groundwater is obtained from coastal aquifer. It has characterized coastal aquifer by transient water levels, variable salinity and water density distribution and heterogeneous hydraulic properties [2]. Generally, the source of freshwater that recharge coastal aquifers are direct from precipitation, river or from irrigation. As it is located near the coastline, groundwater in the coastal aquifer is vulnerable to saltwater intrusion phenomenon due to global sea level rise and overpumping [2-5]. Other contributor for the rise of salinity in coastal aquifer is suggested to be due to meteoric origin, water-rock interaction, salts from irrigation, wastewater, road salt and gypsum applied to enhance agricultural soil quality [6-8].

The status of groundwater quality should be monitor consistently so that the appropriate usage of groundwater can be establish. Without a proper management, this valuable groundwater can turn into a threat to the consumers, settlements and users in the coastal area. Peoples that living and depend on groundwater along Bangladesh coast suffered hypertension to sudden increased in salinity due to saltwater intrusion [9]. National Water Quality standards have stated that water with salinity more than $2.0 \%$ (Class IV) is not suitable for drinking. If the water contains less than $0.5 \%$ of salinity (Class 1), it is safe to consume without further treatment. However, appropriate treatment is required before the consumption if it is containing $0.5 \%$ to $1.0 \%$ of salinity (Class II). In order to preserve coastal groundwater, the sources of saline water and mechanisms of mobility need to be identify so that, fresh groundwater resources can be sustained [10]. Three common methods used for water quality assessment in coastal areas are hydrogeochemical methods, geophysical investigations and multivariate technique $[8,11]$. In this study, hydrogeochemical method is adopt to understand the hydrochemical temporal variations, so that the potential contamination of saltwater into coastal groundwater can be identified. 


\section{Methodology}

\subsection{Study Area}

PT000017 monitoring well is located at Kampung Padang Maras in Kuala Terengganu district. Terengganu is located on the east coast of Peninsular Malaysia. The exact location of PT000017 is at latitude $5^{\circ} 25^{\prime} 19.36^{\prime \prime} \mathrm{N}$ and longitude $103^{\circ} 2$ ' $26.19^{\prime \prime} \mathrm{E}$. The size of Terengganu is approximately $1,295,638.3$ hectares with coastline bordered by South China Sea and stretching $225 \mathrm{~km}$ from Besut (north) to Kemaman (south). The elevation profile of Kuala Terengganu area is approximately at $4.0 \mathrm{~m}$ to $16.0 \mathrm{~m}$ above mean sea level. Terengganu received an average rainfall of \pm 400 $\mathrm{mm}$ per annum during the northeast monsoon season from November to February, meanwhile $\pm 190 \mathrm{~mm}$ per annum during the other months. Its average temperature is from $31^{\circ} \mathrm{C}$ to $33^{\circ} \mathrm{C}$ throughout the year. The climate of the study area is hot and humid throughout the year because Malaysia is part of a tropical country. This climate conditions were controlled by the four monsoons present at the region which are the Northeast monsoon, Southwest monsoon and two inter-monsoons [12-13].

\subsection{Data Collection}

The groundwater quality data of PT000017 monitoring well was collected for seven years which was from 2006 until 2012 by the Department of Mineral and Geosciences Terengganu. The measured water quality parameters involved in this study are calcium $(\mathrm{Ca})$, magnesium $(\mathrm{Mg})$, sodium $(\mathrm{Na})$, potassium $(\mathrm{K})$, carbonate $(\mathrm{CO} 3)$, bicarbonate $(\mathrm{HCO} 3)$, chloride $(\mathrm{Cl})$, sulphate $(\mathrm{SO} 4)$ and total dissolved solids (TDS). Data treatment is carried out on all reading values that below and over detection limit. Values below detection limit were set to half meanwhile, values over detection limit were set to half and added by its original values. Data was sorted according to season before projected into piper and hydrochemical facies evolution diagram.

\subsection{Piper Diagram}

Piper diagram is a combination of two trilinear plots and a centra diamond plot [14-16]. One trilinear plot is for plotting major cations $(\mathrm{Ca} 2+, \mathrm{Mg} 2+, \mathrm{Na}+$ and $\mathrm{K}+)$ and another trilinear plot is for plotting major anions (Cl-, CO32-, $\mathrm{HCO} 3-$ and SO42-). The central diamond plot act as a field where the points from cations and anions trilinear plots are projected [17]. The diamond plot displays the overall chemical character of the water and determined which water types is the groundwater samples [17]. Subsequently, the factors affecting groundwater quality in coastal aquifers can be identify [18]. Diamond plot can be divided into six domains that represent six water types where domain I represents $\mathrm{Ca}-\mathrm{HCO} 3$ water type; domain II represents $\mathrm{Na}-\mathrm{Cl}$ water type; domain III represents mixed $\mathrm{Ca}-\mathrm{Na}-\mathrm{HCO} 3$ water type; domain IV represents mixed $\mathrm{Ca}-\mathrm{Mg}-\mathrm{Cl}$ water type; domain $\mathrm{V}$ represents $\mathrm{Ca}-\mathrm{Cl}$ water type; and domain VI represents Na-HCO3 water type $[8,19,20]$. In this study, piper diagram is plotted by using GW_Chart Calibration Plots: A Graphing Tool for Model Analysis software. GQIpiper (mix) horizontal line defined the mixing ratio of saline water (domain II) and freshwater (domain I) that ranging from 0 for hypersaline water to 100 for highly freshwater. GQIpiper (dom) vertical line defined the other domains. The value for GQIpiper (mix) (1) and GQIpiper (dom) (2) were computed by following the equations:

GQIpiper $($ mix $)=\left[(\mathrm{Ca} 2++\mathrm{Mg} 2+)\right.$ $\Sigma$ Cations $+\left(\mathrm{HCO}^{-}\right)$ ¿Anions] $\times 50($ in $\mathrm{meq} / \mathrm{l})$

GQIpiper $($ dom $)=\left[(\mathrm{Na}++\mathrm{K}+) \Sigma\right.$ Cations $+\left(\mathrm{HCO}^{-}\right) \Sigma$ Inions $]$ $\times 50($ in $\mathrm{meq} / \mathrm{l})$

\subsection{Hydrochemical Facies Evolution Diagram (HFE-D)}

HFE-D diagram is used to interpret whether groundwater samples has gone through seawater intrusion or freshening stages. It can be determined based on the evolution of the hydrochemical facies [21-22]. Hydrochemical data $(\mathrm{Ca} 2+, \mathrm{Mg} 2+, \mathrm{Na}+, \mathrm{K}+, \mathrm{Cl}-, \mathrm{HCO} 3-$ and SO42-) is plotted in HFE-D diagram based on the percentages of major cations and anions. This diagram follows the concept of cation exchange reaction (3) [23]:

$\mathrm{Na}++12 / \mathrm{Ca}-\mathrm{X} 2 \leftrightarrow \mathrm{Na}-\mathrm{X}+12 / \mathrm{Ca} 2+$

\section{Results and Discussion}

Piper diagram has been designed by calculation of GQIPiper (mix) and GQIPiper (dom) indexes for samples collected during wet period (Fig. 1a) and dry period (Fig. 1b). Results show that in wet period, groundwater sample collected during 2008 (W08) is located in domain II that represent mixed $\mathrm{Ca}-\mathrm{Na}-\mathrm{HCO} 3$ water type (saline water). Samples collected during 2006 (W06), 2009 (W09) 2010 (W10) and 2012 (W12) are in domain III that represents mixed $\mathrm{Ca}-\mathrm{Na}-\mathrm{HCO} 3$ water type meanwhile, sample collected during 2007 (W07) is in domain I (Ca-HCO3 water type). During dry period, number of samples characterized as $\mathrm{Ca}-\mathrm{Na}-\mathrm{HCO} 3$ water type (domain II) has been increased to 5 samples which had been collected during 2006 (D06), 2007 (D07), 2008 (D08), 2010 (D10) and 2012 (D12). Samples collected during 2009 (D09) and 2011 (D11) are in domain I.

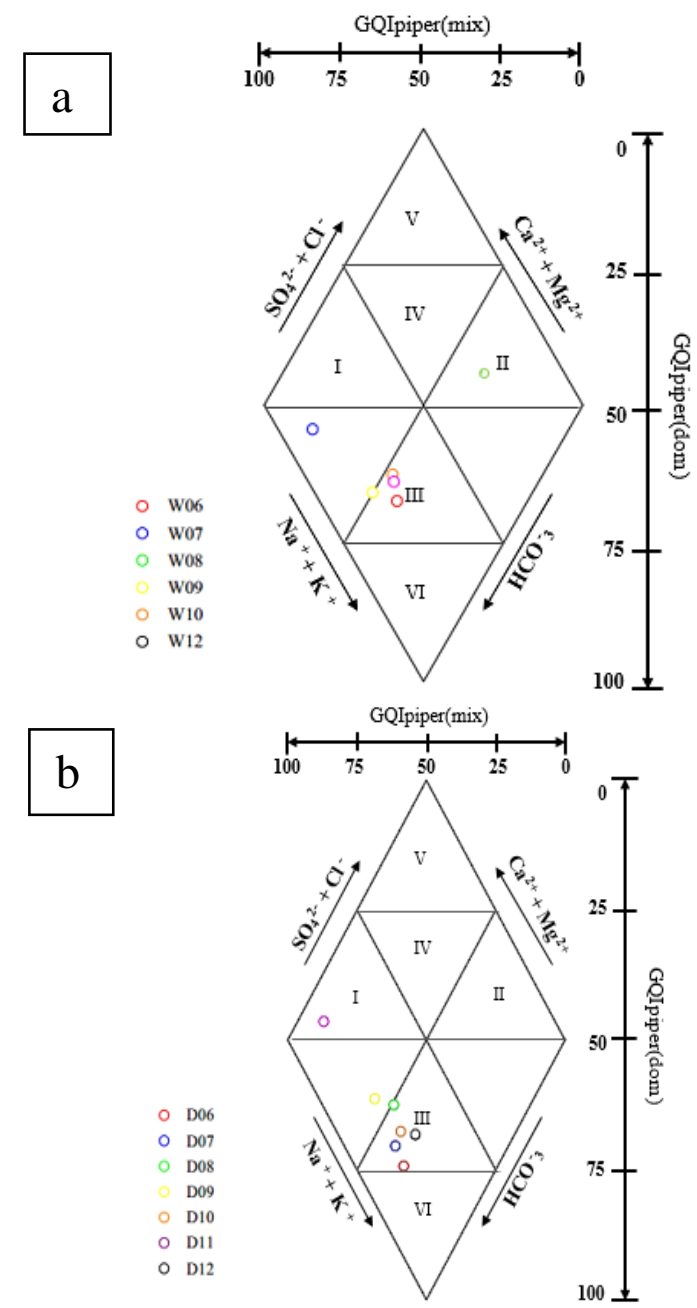

Fig. 1: Piper Diagram of groundwater samples collected during wet $\mathrm{p}$ riod (a) and dry period (b) 
Dry period is dominated by mixed $\mathrm{Ca}-\mathrm{Na}-\mathrm{HCO} 3$ water type (domain II) meanwhile, wet period is dominated by mixed $\mathrm{Ca}-\mathrm{Na}-$ HCO3 water type (domain III). Generally, the amount of rainfall received during wet period is more than dry period. The addition of freshwater into groundwater and sea water has led to freshening process where the level of water salinity is reduced. During dry season, other than less occurrence of rainfall events, the temperature is slightly elevated. High temperature causes an increase in evaporation process of water. Some liquid is removed from groundwater or sea water during evaporation and the concentration of substance within the water is increase. In this case, sea water and groundwater became more salty and it explains why the geochemistry of groundwater samples during dry period is dominated by mixed $\mathrm{Ca}-\mathrm{Na}-\mathrm{HCO} 3$ water type (saline water). Furthermore, the groundwater pumping activity for agriculture uses also encourage the entry of sea water into groundwater.

Subsequently, HFE-D diagram is used to get a detailed recognition of the facies evolution sequence during recharge and intrusion events $[8,21]$. The HFE diagram forgroundwater samples for both wet and dry periods is presented in Fig. 2. Results indicate that all groundwater samples during wet and dry periods were in freshening stage except for the sample collected during wet period in 2007 (W07) which was in the intrusion stage. For wet period, W06, W10 and W12 samples have Na-HCO3 facies, W07 sample has $\mathrm{Ca}-\mathrm{HCO} 3$ facies, W08 sample has Na-SO4 facies meanwhile, W09 sample has MixNa- HCO3 facies. For dry period, D06, D07, D08, D10 and D12 samples have Na-HCO3 facies, D09 sample has MixCa-HCO3 facies meanwhile, D11 sample has Ca-HCO3 facies.

In this case, freshwater corresponds to $\mathrm{Ca}-\mathrm{HCO} 3 / \mathrm{SO} 4$ facies (13), meanwhile seawater corresponds to $\mathrm{Na}-\mathrm{C} 1$ facies (4). The succession of facies along the line of mixing (A) (4-7-10-13) (Fig. 2) shows that groundwater samples has simple binary mixing with little or no interference of base-exchange reactions. For dry period, groundwater samples is experiencing the freshening stage through the 1-5-9-13 evolution. Groundwater experienced direct exchange process from 2006 until 2009 where groundwater gain $\mathrm{Ca}+$ and cede $\mathrm{Na}+$ but in 2010, groundwater is experiencing reverse exchange process where the groundwater is gaining $\mathrm{Na}+$ and cede $\mathrm{Ca}+$. In 2011, groundwater experienced direct exchange process and again having reversed exchange process in 2012. For wet period, groundwater sample undergone 1-5-9-13 evolution of freshening stage. Direct exchange process took place from 2006 until 2007 and later was overtook by reversed exchange process in 2008. From 2008 until 2012, direct exchange processes occur slowly.

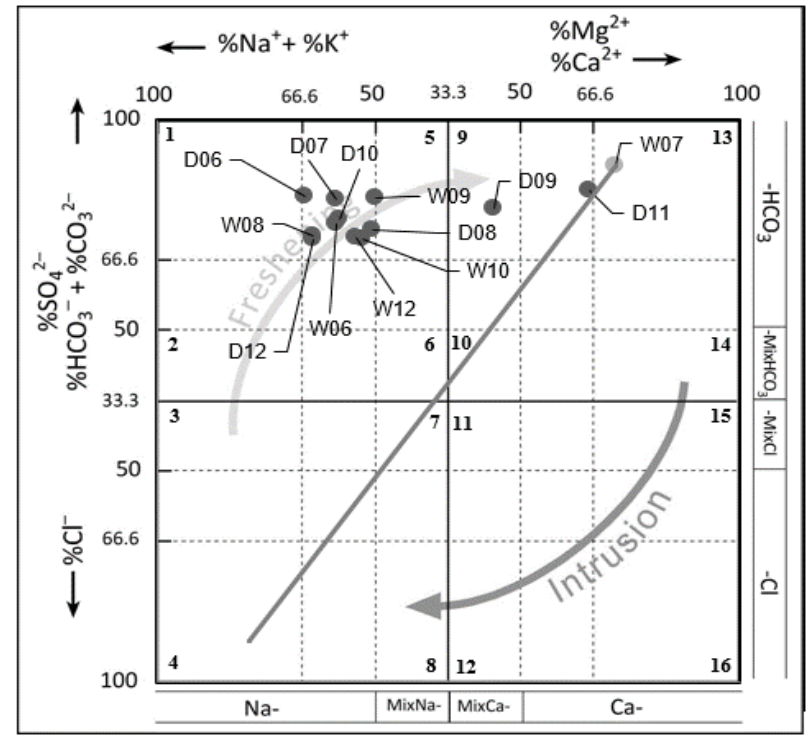

Fig. 2: HFE-D diagram for PT000017 groundwater samples in wet and dry periods

\section{Conclusion}

Piper diagram and HFE-D diagrams constructed in this study proposed a temporal variation in coastal groundwater for PT000017 monitoring well due to seasonal changes. A comparison made between piper diagram of wet and dry periods show that the dry period is dominated by mixed $\mathrm{Ca}-\mathrm{Na}-\mathrm{HCO} 3$ water type or saline water, meanwhile wet period is dominated by mixed $\mathrm{Ca}-\mathrm{Na}-$ HCO3 water type. This is due to the addition of freshwater during wet period due to rainfall that lead to freshening phase of groundwater. HFE-D diagram is also suggesting a freshening processes occur in the aquifer as the hydrochemical facies of the major cations and anions of groundwater of both dry and wet periods show a 1-5-9-13 evolution.

\section{Acknowledgement}

The authors would like to acknowledge the Minerals and Geoscience Department Malaysia under the Ministry of Natural Resources and Environment, Malaysia, for giving us permission to utilize groundwater quality data. This research is fully supported by FRGS/2/2014/STWN06/UNISZA/01/1(RR 082) research grant, and thank the East Coast Environmental Research Institute (ESERI), Universiti Sultan Zainal Abidin (UniSZA) for giving advice, guides, support and for the use of their research facilities.

\section{References}

[1] Rosli, N. A., Zawawi M. H., \& Bustami, R. A. (2011). Salak river water quality identification and classification according to physicchemical characteristics. Proceeding Engineering, 50, 69-77.

[2] Werner, A. D., Bakker, M., Post, V. E. A., Vandenbohede, A., Lu, C., Ataie-ashtiani, B., Simmons, C. T., \& Barry, D. A. (2013). Seawater intrusion processes, investigation and management: $\mathrm{Re}$ cent advances and future challenges. Advances in Water Resources, 51, 3-26.

[3] Priyanka, B. N., \& Mahesha, A. (2015). Parametric Studies on Saltwater Intrusion into Coastal Aquifers for Anticipate Sea Level Rise. Aquatic Procedia, 4, 103-108.

[4] Muhd. Barzani Gasim, Azman Azid, Norsyuhada Hairoma, Nadzifah Yaakub, Haniff Muhamad, Fazureen Azaman and Noorjima Abdul Wahab. 2017. Study on Selected Parameters of Groundwater Quality Based on Different Tides, East Coast of Terengganu, Malaysia. Asian Journal of Applied Sciences 10 (1), 18-24

[5] M.B. Gasim, H. Juahir, A.Azid, M.K.A. Kamarudin, A.R. Hassan, N. Hairoma, Sokono, B. Subartini, P.P. Damayanti and S. Supian. 2018. Potential of Sea Level Rise Impact on South China Sea: Prelimanary Study in Terengganu, Malaysia. J.Fundam.Appl.Scie 10 (1S), 156-168.

[6] Mollema P. N., Antonellini M., Dinelli E., Gabbianelli G., Greggio N., \& Stuyfzand P. J. (2013). Hydrochemical and physcical processes influencing salinization and freshing in Mediterranean lowlying coastal environments. Applied Geochemical, 34, 207-221.

[7] Bouzourra H., Ra B., Elango L., Slama F., \& Ouslati N. (2014). Characterization of mechanisms and processes of groundwater salinization in irrigated coastal area using statistics, GIS, and hydrogeochemical investigations. Environmental Science and Pollution Research.

[8] Amiri, V., Nakhaei, M., Lak, R., \& Kholghi, M. (2015). Assessment of seasonal groundwater quality and potential saltwater intrusion: a study case in Urmia coastal aquifer (NW Iran) using the groundwater quality index (GQI) and hydrochemical facies evolution diagram (HFE-D). Stochastic Environmental Research and Risk Assessment, 1-12.

[9] Khan, A. E., Ireson, A., Kovats, S., Mojumder, S. K., Khusru, A., Rahman, A., \& Vineis, P. (2011). Drinking water salinity and maternal health in coastal Bangladesh: Implications of climate change. Environmental Health Perspectives, 119, 1328-1332.

[10] Gibbs M. S., Dandy G. C., \& Maier H. R. (2013). Assessment of the ability to meet environmental water requirements in the Upper South East of South Australia. Stochastic Environmental Research and Risk Assessment. 
[11] Azid, A., Juahir, H., Toriman, M. E., Kamarudin, M. K. A., \& Gasim, M. B. (2015). Coastal erosion measurement along Tanjung Lumpur to Cherok Paloh, Pahang during the northeast monsoon season. Jurnal Teknologi, 74(1), 27-34

[12] Toriman, M. E., Gasim, M. B., Ariffin, N. H., Muhamad, H., \& Hairoma, N. (2015). The Influence of Tidal Activities on Hydrologic Variables of Marang River, Terengganu, Malaysia. Malaysian Journal of Analytical Sciences, 19(5), 1099-1108

[13] Gasim, M. B., Toriman, M. E. H., Abas, A., Islam, M., \& Tan, C. C. (2008). Water quality of several feeder rivers between two seasons in Tasik Chini, Pahang. Sains Malaysiana, 37(4), 313-321

[14] Piper, A.M. (1944). A graphic procedure in the geochemical interpretation of water-analyses. Transactions - American Geophysical Union, 25, 914-923.

[15] Güler, C., Thyne, G.D., McCray, J.E., \& Turner, A.K. (2002) Evaluation of graphical and multivariate statistical methods for classification of water chemistry data. Hydrogeological Journal, 10, 455-474.

[16] Iranmanesh, A., Locke II, R. A., \& Wimmer, B. T. (2014). Multivariate Statistical Evaluation of Groundwater Compliance Data from the Illinois Basin - Decatur Project. Energy Procedia, 63, 3182-3194.

[17] Magyar, N., Hatvani, I. G., Székely, I. K., Herzig, A., Dinka, M., \& Kovács, J. (2013). Application of multivariate statistical methods in determining spatial changes in water quality in the Austrian part of Neusiedler See. Ecological Engineering, 55, 82-92.

[18] Prasanna, M. V., Chidambaram, S., \& Srinivasamoorthy, K. (2010) Statistical analysis of the hydrogeochemical evolution of groundwater in hard and sedimentary aquifers system of Gadilam river basin, South India. Journal of King Saud University - Science, 22, 133-145.

[19] Subramani T., Elango L., \& Damodarasamy S. (2005). Groundwater quality and its suitability for drinking and agricultural use in Chithar River Basin, Tamil Nadu, India. Environmental Geology, 47(8), 1099- 1110

[20] Prasanth S. S., Magesh N., Jitheshlal K., Chandrasekar N., \& Gangadhar K. (2012). Evaluation of groundwater quality and its suitability for drinking and agricultural use in the coastal stretch of Alappuzha District, Kerala, India. Applied Water Science, 2(3), 165-175.

[21] Giménez-Forcada, E. (2010). Dynamic of Sea Water Interface using Hydrochemical Facies Evolution Diagram (Vol. 48). Spain..x

[22] Giménez-Forcada, E. Sánchez San Román, F.J. (2014). An Excel Macro to plot the HFE-Diagram to identify seawater intrusion phases. Groundwater 2014.

[23] Appelo, C.A.J., \& Postma, D. (2006). Geochemistry, Groundwater and Pollution, 2nd ed. Rotterdam: A. A. Balkema. 